\title{
ERGOTERAPIJOS UŽSIĖMIMŲ EFEKTYVUMAS VAIKŲ, SERGANČIU ŪMINE LIMFOBLASTINE LEUKEMIJA, KASDIENEI VEIKLAI IR GYVENIMO KOKYBEI
}

\author{
Justinas Blaževičius, Aurelija Šidlauskienė \\ Vilniaus universiteto Medicinos fakulteto Reabilitacijos, fizinès ir sporto medicinos katedra
}

Raktažodžiai: ergoterapija, leukemija, gyvenimo kokybė (GK), vaikai, kasdienès veiklos.

\begin{abstract}
Santrauka
Lietuvoje, kaip ir kitose šalyse, vaikai dažniausiai serga ūminèmis limfoblastinèmis leukemijomis (ŪLL) ir centrinès nervų sistemos navikais. Onkohematologinių ligų gydymas chemoterapija dažnai sukelia šalutinius poveikius, kurie gali tiesiogiai paveikti vaikų gyvenimo kokybès sumažèjimą. Dèl chemoterapijos sukeltų neigiamų šalutinių poveikių, sumažèjusios bendros raumenų jègos, pasireiškiančių skausmingų dizestezijų, sensorinių sutrikimų, giliujų sausgyslių susilpnejjimo, balanso ir kordinacijos sutrikimų vaikas nebegali visavertiškai dalyvauti sporto veiklose. Ergoterapijos užsiëmimai padeda vaikams pilnavertiškai dalyvauti kasdieninèse veiklose, kurių dèka gerinama fizinè bei psichinè būklè. Ergoterapijos intervencijos pagrindinis tikslas - gyvenimo kokybės gerinimas. Gyvenimo kokybès pablogèjimas gali turèti įtakos veiklų disbalansui. Iš viso tyrime dalyvavo 54 pacientai, sergantys ūmine limfoblastine leukemija. Visiems tiriamiesiems buvo atlikta 15 ergoterapijos procedūrų. Tyrimo metu buvo vertinami šie kriterijai: skausmas, nuovargis, nerimas, gyvenimo kokybė, dinamometrija, psichologinè būklè. Taikant ergoterapijos užsièmimų procedūras nustatytas statistiškai reikšmingas pagerèjimas visose amžiaus grupèse, vaikai geriau ịvertino savo gyvenimo kokybę. Nustatyta, kad ergoterapijos užsièmimai turejjo statistiškai reikšmingą įtaką vaikų dinamometrijos rezultatams.
\end{abstract}

\section{Ivadas}

Lietuvos vėžio registro duomenimis, 2010-2011 metais kraujo vėžys (leukemija) buvo dažniausiai diagnozuojama piktybinių navikų rūšis vaikų amžiaus grupejje nuo gimimo iki 14 metu [1-2]. Nuo 2011 iki 2015 metų onkohematologine liga susirgo ir dèl gydymo kreipèsi ị Všị Vilniaus universiteto ligoninės Santaros klinikų filialo Onkohematologijos skyrių 208 vaikai, iš jų ŪLL susirgo 94 vaikai. Išsivysčiusiose šalyse kraujo vėžys yra antra pagal dažnumą mirties priežastis tarp vaikų, vyresnių nei 1 metai. Taikant Vinkristino chemoterapiją dažniausiai pažeidžiama rankų motorika [3]. Kortikosteroidai sąlygoja avaskulinę nekrozę daugiausia svorio gaunančiuose sąnariuose. Taip pat taikant chemoterapiją padideja rizika išsivystyti osteoporozei, smegenu disfunkcijai ar trumpalaikei paraplegijai [4]. Onkologinès ligos ir jų gydymas turi stiprų poveikị kasdienėms vaikloms bei dalyvavimui mégejiššose arba sudètingesnio lygio sporto srityse [5]. Dèl chemoterapijos sukeltų neigiamų šalutinių poveikių sumažejjusi bendra raumenų jèga, pasireiškiančios skausmingos dizestezijos, sensoriniai sutrikimai, giliujų sausgyslių susilpnejimas, balanso ir kordinacijos sutrikimai turi neigiamą ittaką vaikų fiziniams gebėjimams, dèl kurių vaikas nebegali pilnavertiškai dalyvauti sportinèse veiklose [6-7].

Darbo tikslas: įvertinti ergoterapijos užsièmimų įtaką vaikų kasdienėms veikloms ir gyvenimo kokybei, sergant ümine limfoblastine leukemija.

\section{Tyrimo objektas ir metodai}

Tyrimo objektas: vaikų, sergančių ūmine limfoblastine leukemija, kasdienių veiklų atlikimas ir gyvenimo kokybė hospitalizacijos metu.

Tyrimo metodai. Tyrime dalyvavo 54 pacientai, sergantys ūmine limfoblastine leukemija, iš jų 51,85 proc. berniukų ir 48,15 proc. mergaičių. Tyrimas buvo atliekamas anketinès apklausos būdu. Tyrimas vyko Všt Vilniaus universiteto ligoninès Santaros klinikų filialo Vaikų ligonineje, Onkohematologijos skyriuje nuo $2013 \mathrm{~m}$. rugsèjo iki $2015 \mathrm{~m}$. kovo mènesio. Visiems tiriamiesiems buvo atlikta 15 ergoterapijos procedūrų. Tiriamieji buvo ištirti du kartus: ergoterapijos užsiemimų pradžioje ir pabaigoje. Visi sergantys vaikai gulejo su lydinčiu asmeniu. Pirminio ištyrimo metu buvo 
taikomas nestruktūrizuotos apklausos metodas. Vaikai ir jų tèvai buvo apklausiami tiesioginiu būdu, siekiant išsiaiškinti jų užimtumą, kasdieninių veiklų atlikimą ir pasitenkinimą jomis, fizinius ir emocinius sunkumus. Pacientai buvo atrinkti atsitiktinès atrankos budu. Tyrime pacientų skausmo intensyvumui nustatyti naudota PedsQL skausmo skalè, gyvenimo kokybei - PedsQL gyvenimo kokybės klausimynas, PedsQL nuovargio skalès modifikuotas gyvenimo kokybės klausimynas, kasdienėms veikloms - KVVT ir dinamometrijos rodmenys, psichologinei būklei - HAD (depresijos ir nerimo ịvertinimo) skale ir PedsQL nerimo skalè. Duomenu analizè atlikta naudojant statistinès analizès „IBM SPSS statistics 20“ ir „Excel 2013“ programas.

\section{Rezultatai ir jų aptarimas}

Tyrimo metu buvo analizuojami 54 vaikų, sergančiu ŪLL ligomis, ir jų tèvų atsakymų ị PedsQL onkologinėms ligoms pritaikytą skalę, rezultatai. Analizuojant vaikų ir jų

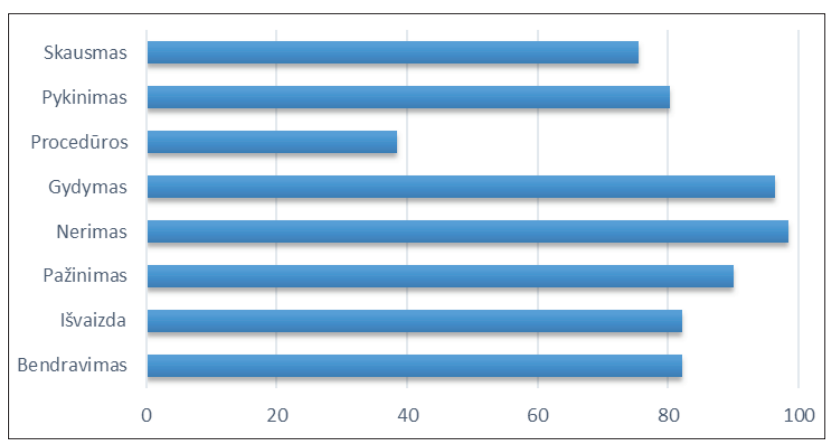

1 pav. Vaikų onkologinėms ligoms pritaikytos PedsQL skalès vaikų vertinimas po ergoterapijos užsièmimų

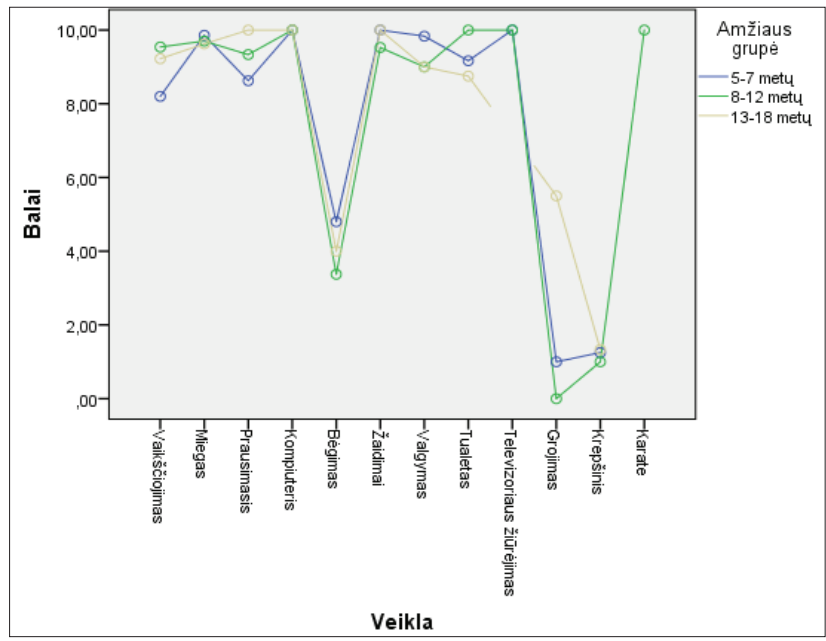

2 pav. Veiklų atlikimo pasitenkinimas po ergoterapijos užsièmimų, pagal amžiaus grupes tėvų pateiktus duomenis, siekta ne tik nustatyti ergoterapijos procedūrų efektyvumą, bet aprašyti sergančių vaikų GK bei palyginti ją pagal amžiaus grupes ir įvertinti vaikų, jų tėvų GK vertinimo skirtumus. Tyrime dalyvavusių vaikų amžius - nuo 5 iki 18 metų (vidurkis \pm SD 9,39 $\pm 3,6$ ). Analizuojant PedsQL onkologinems ligoms pritaikytos skalès rezultatus pirminio ištyrimo metu, nustatyta, kad ŪLL sergantys vaikai visose amžiaus grupèse daugiausia sunkumų turèjo dèl procedūrų baimès $(31,79 \pm 31,97)$, gydymo metu patiriamo skausmo $(54,40 \pm 24,18)$, bendravimo $(55,40 \pm 18,96)$ bei gydymo eigoje atsiradusio pykinimo $(57,31 \pm 13,89)$. Vaikus mažiausiai kankino baimè dèl paskirto gydymo $(85,96$ $\pm 12,42)$, nerimas dèl pakitusios išvaizdos $(82,41 \pm 9,67)$, mažiausiai turejo pažinimo sunkumų $(83,52 \pm 10,35)$ ar nerimavo dèl savo ateities $(92,59 \pm 9,8)$.

Atlikus pakartotinį vertinimą, visose amžiaus grupèse matome išlikusią procedūrų baimę $(38,49 \pm 25,7)$, tačiau kitose vertinimo srityse yra ženklus pagerëjimas: nerimas $(98,46 \pm 3,27)$ ir gydymas $(96,45 \pm 5,51)$ vaikams kèlè mažiausiai nepasitenkinimo (1 pav.).

Suskirsčius atsakymus pagal amžiaus grupes, 5-7 metų amžiaus grupèje vaikams daugiausia problemų buvo dèl skausmo patiriamo procedūrų metu, 8-12 metų amžiaus grupèje, taip pat buvo būdingas fizinis skausmas, sukeliamas gydymo metu, 13-18 metų amžiaus grupeje, daugiausia sunkumų kilo dèl pykinimo, atsiradusio gydymo metu. Pakartotinio tyrimo metu po 15 procedūrų nustatyta, kad bendras balų sumos pagerẻjimas nuo 67,92 $\pm 8,75$ balų iki $80,47 \pm 7,01$, pokytis statistiškai reikšmingas $(p<0,05)$. 5-7 metų amžiaus

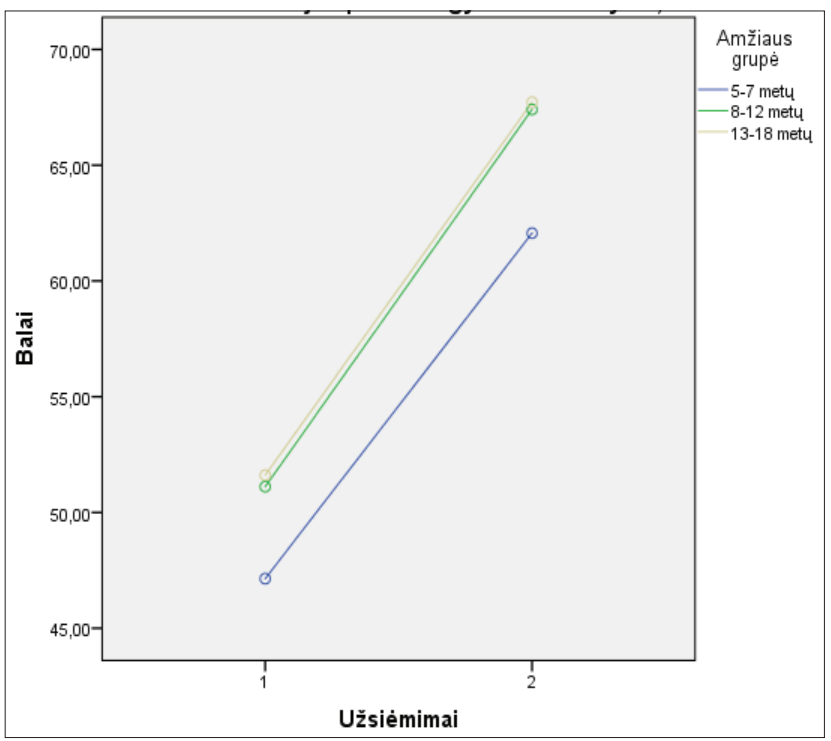

3 pav. Ergoterapijos užsiėmimų poveikis vaikų gyvenimo kokybei vaikų vertinimu 
vaikai geriau ịvertino savo problemų sumažèjimą bendraujant su medicinos personalu bei sumažèjus pykinimą, kuris buvo gydymo metu $(p<0,05)$. 8-12 metų amžiaus grupejje didžiausias teigiamas pokytis matomas bendraujant su medicinos personalu ir sumažejęs pykinimas gydymo metu, pokyčiai statistiškai reikšmingi $(p<0,05)$. 13-18 metų amžiaus grupès didžiausi teigiami pokyčiai nustatyti dẻl gydymo metu atsiradusių kognityvinių funkcijų problemų sumažejjimo ir sumažèjusių problemų bendraujant su pesonalu $(p<0,05)$.

Vertinant PedsQL onkologinèmis ligomis sergančių vaikų vertinimo skalès gautus bendrus, vaikų tėvų, rezultatus pirminio ištyrimo metu, nustatyta, kad tèvai, kaip ir ju vaikai, daugiausia iškilusių problemų nustatė dẻl gydymo metu vaikams sukelto skausmo $(35,64 \pm 33,43)$. Apskaičiavus visus rezultatus buvo nustatyta, kad ergoterapijos užsièmimai turejjo statistiškai reikšmingą poveikị vaikams visose amžiaus grupėse $(\mathrm{p}=0,000<0,05)$ tiek tėvų, tiek vaikų požiūriu (1 lentelè).

Analizuojant KVVT rezultatus, išsiaiškinta, kad visi vaikai susidūrẻ su veiklos atlikimo problemomis. Nustatyta, kad ergoterapijos užsièmimai turèjo statistiškai reikšmingą įtaką kasdienes veiklas atlikti $(\mathrm{p}=0,000<0,05)$, poveikis buvo nevienodas visoms veikloms $(\mathrm{p}=0,000<0,05)$, tačiau vienodas visoms amžiaus grupèms $(p=0,194>0,05)$,

1 lentelè. GK vertinimas po ergoterapijos užsièmimų

\begin{tabular}{|c|c|c|c|c|c|}
\hline Subskalė & Amžius & Vaikai & Tèvai & Vidurkis & $P$ reikšmė \\
\hline \multirow[t]{3}{*}{ Skausmas } & 5-7 metai & 67,86 & 64,29 & 66,07 & 0,083 \\
\hline & 8-12 metų & 78,13 & 74,48 & 76,30 & 0,050 \\
\hline & 13-17 metur & 86,11 & 79,17 & 82,64 & 0,051 \\
\hline \multirow[t]{3}{*}{ Pykinimas } & 5-7 metai & 74,52 & 69,29 & 71,90 & 0,000 \\
\hline & 8-12 metų & 84,58 & 83,13 & 83,85 & 0,005 \\
\hline & 13-17 metų & 82,44 & 80,78 & 81,61 & 0,081 \\
\hline \multirow[t]{3}{*}{ Procedūros } & 5-7 metai & 16,27 & 14,68 & 15,48 & 0,329 \\
\hline & $8-12$ metur & 47,36 & 47,01 & 47,19 & 0,770 \\
\hline & 13-17 metu & 66,67 & 62,96 & 64,81 & 0,104 \\
\hline \multirow[t]{3}{*}{ Gydymas } & 5-7 metai & 96,03 & 95,24 & 95,63 & 0,428 \\
\hline & $8-12$ metur & 96,18 & 95,83 & 96,01 & 0,328 \\
\hline & 13-17 metur & 98,15 & 97,22 & 97,69 & 0,347 \\
\hline \multirow[t]{3}{*}{ Nerimas } & 5-7 metai & 98,81 & 98,81 & 98,81 & 1,000 \\
\hline & $8-12$ metų & 98,61 & 98,96 & 98,78 & 0,328 \\
\hline & 13-17 metų & 97,22 & 95,37 & 96,30 & 0,347 \\
\hline \multirow[t]{3}{*}{ Pažinimas } & 5-7 metai & 87,38 & 86,90 & 87,14 & 0,162 \\
\hline & 8-12 metų & 91,04 & 90,83 & 90,94 & 0,802 \\
\hline & 13-17 metų & 93,89 & 89,44 & 91,67 & 0,035 \\
\hline \multirow[t]{3}{*}{ Išvaizda } & 5-7 metai & 83,73 & 84,92 & 84,33 & 0,186 \\
\hline & $8-12$ metų & 81,60 & 81,25 & 81,42 & 0,328 \\
\hline & 13-17 metur & 80,56 & 78,70 & 79,63 & 0,347 \\
\hline \multirow[t]{3}{*}{ Bendravimas } & 5-7 metai & 69,05 & 73,41 & 71,23 & 0,038 \\
\hline & $8-12$ metur & 90,97 & 96,53 & 93,75 & 0,006 \\
\hline & 13-17 metur & 89,81 & 98,15 & 93,98 & 0,009 \\
\hline
\end{tabular}

o ergoterapijos užsièmimų poveikis skirtingoms amžiaus grupèms ir veikloms statistiškai reikšmingai nesiskyrè $(p=0,377>0,05)$. Ergoterapijos užsièmimai turejjo statistiškai reikšmingą įtaką pasitenkinimui kasdienių veiklų atlikimu $(\mathrm{p}=0,000<0,05)$. Užsièmimų poveikis buvo nevienodas visoms veikloms $(\mathrm{p}=0,000<0,05)$, tačiau vienodas visoms amžiaus grupèms ( $\mathrm{p}=0,182>0,05)$ ( 2 pav.).

Ergoterapijos užsiėmimų poveikis skirtingoms amžiaus grupèms ir veikloms statistiškai reikšmingai nesiskyrè $(p=0,513>0,05)$. Ergoterapijos užsièmimai turejjo statistiškai reikšmingą įtaką vaiku dinamometrijos rezultatams $(p=0,000<0,05)$, šis poveikis buvo skirtingas tarp amžiaus grupių ( $\mathrm{p}=0,000<0,05)(3$ pav.).

Vertinant rankų dinamometrijos rezultatų itaką vaikų, sergančių ŪLL, gyvenimo kokybei bei kasdienei veiklai atlikti nustatyta, kad ergoterapijos užsiemimai turèjo statistiškai reikšmingą įtaką vaikų dinamometrijos rezultatams $(\mathrm{p}=0,000<0,05)$, šis poveikis buvo skirtingas tarp amžiaus grupių ( $\mathrm{p}=0,000<0,05)$. Tikrinant rankų dinamometrijos daromą itaką vaikų gyvenimo kokybei ir kasdienei veiklai bei pasitenkinimui, nustatyta, kad 5-7 metų amžiaus grupéje dinamometrijos pokytis buvo susijęs statistiškai reikšmingu ( $p=0,046<0,05)$ ryšiu tik su gyvenimo kokybès pokyčiu, ryšys teigiamas (didesnis dinamometrijos pokytis skatina didesnį gyvenimo kokybės pokytị), visais kitais atvejais dinamometrijos pokytis neturejo jokios ịtakos nei gyvenimo kokybei, nei kasdienių veiklų vertinimui.

Pasaulyje vis daugiau atliekama tyrimų, kuriuose vertinama onkologine liga sergančių vaikų gyvenimo kokybe ar gyvenimo pokyčiai. Annelies Hartman (2008) teigia, kad ligos atveju vaiko savigarba sumenkèja. Vaikams savigarba priklauso nuo kelių faktorių. Vienas iš jų - atletinẻ kompetencija. Vaikai jaučia savigarbą, „būdami tokie pat kaip jų varžovai“, „sugebantys prisitaikyti grupeje“ “ ir „nebūdami skirtingi" [8]. Panašus tyrimas, vertinantis gyvenimo kokybę, buvo atliktas 2008 metais Lietuvoje, J. Makari apsigintoje daktaro disertacijoje buvo ištirta 112 vaikų, kuriems buvo neseniai diagnozuota onkologinė liga [9]. 2009 m. Dehkordi A. ir kt. atliko tyrimą, kurio metu nustate, kad pacientu, gaunančių keletą ir daugiau chemoterapijos ciklų, gyvenimo kokybè yra geresnè, viena iš problemų buvo baimè, nerimas dèl ateities [10]. Taip pat 2016 metais atliktame tyrime buvo vertinamos su sveikata susijusios gyvenimo kokybès ir poreikių sąsajos, kurių metu nustatyta, kad yra stiprus ryšys tarp ligos simptomų ir emocinio funkcionavimo [11]. Visuose tyrimuose teigiama, kad siekiant pagerinti vaikų, sergančiu onkologine liga, gyvenimo kokybę, reikia mažinti socialinę atskirtį, baimes ir nerimą. 


\section{Išvados}

1. 5 - 18 metų vaikai savo fizinę sveikatą ịvertino prasčiau nei psichosocialinę. Pagrindinès vaikų nerimo ir nusiskundimų priežastys: procedūrų baimès, gydymo metu patiriamas bei gydymo eigoje atsiradęs pykinimas. Vaikams, sergantiems ŪLL ligomis, taikant ergoterapijos užsiemmimų procedūras nustatytas statistiškai reikšmingas pagerẻjimas visose amžiaus grupèse.

2. 5-18 metų vaikų gyvenimo kokybès aspektus tėvai vertino panašiai kaip ir jų vaikai. Tačiau tèvai dažniau negu vaikai išskyrè dèl ligos atsiradusius fizinès sveikatos, emocijų, bendravimo su medikais ir bendro nuovargio sunkumus.

3. Ivertinus vaikų, sergančių ŪLL ligomis, veiklų atlikimo ir pasitenkinimo jomis pokyčius prieš ir po ergoterapijos užsièmimų, naudojant Kanadietiškos veiklos vertinimo testą, nustatytas statistiškai reikšmingas teigiamas pokytis atliekant kasdienes veiklas $(\mathrm{p}=0,000<0,05)$.

4. Ergoterapijos užsièmimai turèjo statistiškai reikšmingą itaką vaikų dinamometrijos rezultatams $(\mathrm{p}=0,000<0,05)$, šis poveikis buvo skirtingas tarp amžiaus grupių $(\mathrm{p}=0,000<0,05)$.

\section{Literatūra}

1. Vilniaus universiteto Onkologijos institutas. Vèžio kontrolès ir profilaktikos centras Vèžys Lietuvoje 2010 metais. Sudarè Smailytė, G., Aleknavičienė, B. 2010; 6-8.

2. Vilniaus universiteto Onkologijos institutas. Veežio kontrolès ir profilaktikos centras Vėžys Lietuvoje 2011 metais. Sudarẻ Smailytė G., Aleknavičienė B., 2011; 5-6.

3. Sabarre C, Rassekh S. 51. Vincristine and fine motor function of children with acute lymphoblastic leukemia. Canadian Journal of Occupational Therapy 2015 Jul 11 (4); 237-239.

4. Hartman J.E.M. Motor performance following chemotherapy for childhood cancer. Olandija, 2009; 47-50.

5. Gotte M, Dip, Taraks S, Boos J. Sports in pediatric oncology: the role(s) of physical activity for children with cancer. Journal of Pediatric Hematology/ Oncology 2014; 36:85-90. https://doi.org/10.1097/MPH.0000000000000101

6. Hartman JEM. Motor performance following chemotherapy for childhood cancer. Olandija, 2009; 52-74.

7. Ramchandren S, Leonard M, Mody RJ, Donohue JE, Moyer J, Hutchinson R, Gurney JG. Peripheral neuropathy in survivors of childhood acute lymphoblastic leukemia. Journal of the Peripheral Nervous System 2009; 14:1-11.

https://doi.org/10.1111/j.1529-8027.2009.00230.x

8. Spieth LE, Harris CV. Assessment of health-related quality of life in children and adolescents: an integrative review. J Pediatr Psychol 1996;21(2):175-93.

https://doi.org/10.1093/jpepsy/21.2.175

9. Makari J., Zaborskis A., Labanauskas L., Ragelienė L. Onkologinėmis ligomis sergančių vaikų gyvenimo kokybẻ Lietuvoje. Kauno medicinos universiteto Vaikų ligų klinika, Biomedici- ninių tyrimų institutas, Vilniaus universiteto vaikų ligoninè. Medicina (Kaunas), 2007; 43(9): 726-727.

10.Jokubaitienè A. Onkologinių pacientu su sveikata susijusi gyvenimo kokybė ir psichosocialiniai poreikiai. Vilniaus universitetas, 2016.

11. Dehkordi A, Heydarnejad MS, Fatehi D. Quality of life in cancer patients undergoing chemotherapy. Oman Med J 2009 Jul; 24(3): 204-207.

https://doi.org/10.5001/omj.2009.40

\section{THE INFLUENCE OF OCCUPATIONAL THERAPY ACTIVITIES ON DALY LIVING AND QUALITY OF LIFE OF CHILDREN HAVING ACUTE LYMPHOBLASTIC LEUKAEMIA J. Blaževičius, A. Šidlauskienė}

Key words: acute lymphoblastic leukaemia, occupational therapy, occupation, quality of life, daily activities, children.

Summary

According to the Lithuanian Cancer Registry, in 2010-2011, blood cancer (leukemia) was the most commonly diagnosed type of malignant tumor in the age group of children from birth to age 14 [4-5]. From 2011 to 2015, 208 children became ill with oncohematologic disease and were referred to the Vilnius University Hospital Santaros clinics branch of the Vilnius University Hospital for treatment, of whom 94 children (13) were diagnosed with ULL. In developed countries, blood cancer is the second leading cause of death among children older than 1 year (14).

The use of Vincristine chemotherapy is usually the cause of hand motor damage [6]. Corticosteroids cause avascular necrosis in most weight-bearing joints. Also, chemotherapy increases the risk of developing osteoporosis, may cause brain dysfunction or short-term paraplegia [7].

54 patients, with acute lymphoblastic leukemia, participated in the investigation: 51.85 per cent boys and 48.15 per cent girls. The investigation was conducted in a questionnaire survey manner. The children at the age of 5-18 years assessed their physical health inferior than their psycho-social health. The principal of children's dismay and causes of their complaints: fear of procedures $(31.79 \pm 31.97)$, pain experienced during the treatment $(54.40$ $\pm 24.18)$, communication with the medical staff $(55.40 \pm 18.96)$ and nausea during the treatment. Statistically significant improvement was identified for the children, being ill with ALL, across all the age groups after applying the procedures of occupational therapy activities. The children assessed their quality of life improved.

After assessing the quality of life, the assessment changes of children, being ill with ALL, and their parents, a statistically significant improvement was identified across all the age groups except with distress due to the changed appearance, because the assessment reduced by 0.47 of a point.

Assessing the quality of life of the children, being ill with the ALL, and their parents, the statistically significant medium-strength relationship was identified between the children and their parents ${ }^{\text {* }}$ living quality assessment. The parents assessed the 5-18 year children's living quality aspects similarly to their children. However, 


\section{6}

the parents' opinion differed more frequently than their children due to physical health, emotions, communication with the medical staff and general fatigue difficulties emerging due to the illness. In the age group of 5-7 years, the children and parents' assessments of the PedsQL scales of the children, being ill with oncological diseases, did not differ before the occupational therapy procedures $(p=0.851>0.05)$, meanwhile the parents assess the PedsQL scale better than their children in the older children's age group, and these differences are statistically significant $(\mathrm{p}<0,05)$ (Table 3 ). The children and their parents in the age group of 5-7 years assessed the PedsQL oncological diseases scale in the worst manner, but no statistically significant PedsQL differences were discovered.

Assessing the shifts in the performance and satisfaction of activities of the children, ill with ALL diseases before and after occupational therapy activities, using the Canadian activity assessment test, it was identified that the occupational therapy had a statistically significant impact upon the performance of daily activities $(\mathrm{p}=0.000<0.05)$, its impact was not equal to all activities $(p=0.000<0.05)$, but equal to all the age groups $(p=0.194>0.05)$ and the impact of occupational activities to the different age groups and activities did not differ significantly and statistically $(\mathrm{p}=0.377>0.05)$

Occupational therapy activities had a statistically significant impact upon the children's dynamometry results $(\mathrm{p}=0.000<0.05)$. This impact was different among the age groups $(\mathrm{p}=0.000<0.05)$. It was identified that the dynamometry shift in the age group of 5-7 years was statistically significant $(\mathrm{p}=0.046<0.05)$ in relation to the quality of life shift, this relationship is positive (larger dynamometry shift promotes a larger life quality shift), in all the other cases, the dynamometry shift did not have any impact upon the life quality nor in the assessment of the daily activities.

Correspondence to: justinas.blazevicius.eu@gmail.com

Gauta 2018-02-06 